\title{
ANTIFUNGAL ACTIVITY OF LECTINS AGAINST YEAST OF VAGINAL SECRETION
}

\section{Bruno Severo Gomes* ${ }^{1}$, Ana Beatriz Sotero Siqueira ${ }^{1}$, Rita de Cássia Carvalho Maia ${ }^{4,6}$, Viviana Giampaoli ${ }^{7}$, Edson Holanda Teixeira ${ }^{5}$, Francisco Vassiliepe Sousa Arruda ${ }^{5}$, Kyria Santiago do Nascimento ${ }^{5}$, Adriana Nunes de Lima ${ }^{1}$, Cristina Maria Souza-Motta ${ }^{1}$, Benildo Sousa Cavada ${ }^{5}$, Ana Lúcia Figueiredo Porto ${ }^{2,3}$}

${ }^{1}$ Departamento de Micologia, Universidade Federal de Pernambuco, Recife, PE, Brasil; ${ }^{2}$ Laboratório de Imunopatologia Keizo Asami, Universidade Federal de Pernambuco, Recife, PE, Brasil; ${ }^{3}$ Departamento de Morfologia e Fisiologia Animal, Universidade Federal Rural de Pernambuco, Recife, PE, Brasil; ${ }^{4}$ Centro de Pesquisa Aggeu Magalhães, Fundação Instituto Oswaldo Cruz, Recife, PE, Brasil; ${ }^{5}$ Laboratório de Moléculas Biologicamente Ativas, Universidade Federal do Ceará, Fortaleza, CE, Brasil; ${ }^{6}$ Departamento de Medicina Veterinária. Universidade Federal Rural de Pernambuco, Recife, PE, Brasil; ${ }^{7}$ Departamento de Estatística, Universidade de São Paulo, São Paulo, SP, Brasil.

Submitted: January 29, 2011; Returned to authors for corrections: May 12, 2011; Approved: January 16, 2012.

\begin{abstract}
Lectins are carbohydrate-binding proteins of non-imune origin. This group of proteins is distributed widely in nature and they have been found in viruses, microorganisms, plants and animals. Lectins of plants have been isolated and characterized according to their chemical, physical-chemical, structural and biological properties. Among their biological activities, we can stress its fungicidal action. It has been previously described the effect of the lectins Dviol, DRL, ConBr and LSL obtained from the seeds of leguminous plants on the growth of yeasts isolated from vaginal secretions. In the present work the experiments were carried out in microtiter plates and the results interpreted by both methods: visual observations and a microplate reader at 530nm. The lectin concentrations varied from 0.5 to $256 \mu \mathrm{g} / \mathrm{mL}$, and the inoculum was established between $65-70 \%$ of trammitance. All yeast samples isolated from vaginal secretion were evaluated taxonomically, where were observed macroscopic and microscopic characteristics to each species. The LSL lectin did not demonstrate any antifungal activity to any isolate studied. The other lectins DRL, ConBr and DvioL, showed antifungal potential against yeast isolated from vaginal secretion. These findings offering offer a promising field of investigation to develop new therapeutic strategies against vaginal yeast infections, collaborating to improve women's health.
\end{abstract}

Key words: Yeast, sensitivity, lectins

\section{INTRODUCTION}

Lectins are proteins or glycoproteins belonging to the immune system that bind specifically and reversibly to mono- and oligosaccharides in the form of free or glycoconjugates (glycoproteins and glycolipids). Thus, combined with biological molecules and structures containing these sugars without altering the structure of the glycosidic bonds in

*Corresponding Author. Mailing address: Departamento de Micologia. Micoteca URM, Universidade Federal de Pernambuco, Recife - Brasil.; E-mail: bseverogomes@gmail.com 
covalent binding sites $(11,28,37)$.

They are found widely in animals, plants, fungi, bacteria and viruses $(11,24,29,33)$ but these substances are present in greater quantities in grain legumes and grasses $(1,9,28,41)$. The seeds of legumes such as beans and peas are rich sources of lectins which have been extensively characterized in relation to chemical properties, physical chemistry, structural and biological $(8,27,28,31)$. The parts of plants more susceptible to attack by predators, such as seeds, contain lectins that are in highest concentration. With the exception of chitinases, glucanases and glycosidases, lectins are the only proteins that recognize and bind to glycoconjugates present on the surface of bacteria and fungi or exposed in the intestinal tract of insects and mammals $(33,41)$.

Dioclea violacea, D. rostrata and Canavalia brasiliensis are legumes which are extracted lectins Dviol, DRL, ConBr respectively, which have affinity for glucose and mannose (3, $8,10)$. These lectins showed induction of histamine in mice (19), in vivo protective effect against Leishmania amazonensis infection in BALB/c (6), lymphocyte stimulation in humans (5), stimulating the production of macrophages and lymphocytes in $\mathrm{C} 3 \mathrm{H} /$ Hej (34).

Lonchocarpus sericeus is a legume which is extracted with LSL lectin affinity for $\mathrm{N}$-acetylglucosamine (31). As demonstrated antiinflammatory activity in cases of peritonitis in mice, marked reduction of bacteria that colonized this region (1) and inhibition of neutrophil migration in inflammatory processes (31).

Some studies have reported the antifungal activity of lectins from leguminous plants such as bean Phaseolus vulgaris (8); fruit as pitomba Talisia esculenta (18), jackfruit Artocarpus integrifolia, breadfruit A. incisa (35) and soursop Annona muricata (16), fungi such as Kluyveromyces bulgaricus (36), and Schizophyllum commune (13), nettle Urtica dioica (7), potato (20), wheat germ (14) and Chinese herb Astragalus mongholicus as (40). These lectins are called, respectively: lectins from Phaseolus vulgaris, TEL, "jackin", "frutackin, AML, Kb-CWL I, SCL, UDA, potato lectin, WGA, AMML.

The susceptibility to antifungal activity of lectins has been observed in yeast as Sacchromyces cerevisiae (18, 35, 36), S. bayanus, S. uvarurn, Candida albicans, C. glabrata, Rhodotorula mucilaginosa, Pichia pastoris, Kluyveromyces bulgaricus, $K$. lactis, Schizosacchamyces bulgaricus, $S$. octosporus (36), and filamentous fungi such as Trichoderma viride, T. hamatum (7), Coprinus comatus, Rhizoctonia solani (41), Fusarium oxysporum (14, 16, 40, 41), Colletorichum lindemuthianum (18) F. moniliforme (35) C. musae, F. solani (16), Aspergillus niger (13), Phoma betae, Phycomyces blakesleeanus, Septoria nodorum, Phytophthora erythroseptica (7) F. graminearum (14) Colletorichum sp. Drechslera Turkish origin (40), Botrytis cincerea $(7,40)$.

However, other lectins have no antifungal activity (30, 37, $38,39,42)$ and some showed activating effect on the kinetics of growth of the fungus $(22,32,36)$.

This study aimed to determine the antifungal effect of lectins from leguminous seeds on yeasts isolated from vaginal secretions.

\section{MATERIALS AND METHODS}

\section{Yeasts}

The yeasts were isolated from vaginal secretions of pregnant and non-pregnant women with and without symptoms, for investigation of vulvovaginal yeast infections.

The patients were from the gynecology, pediatrics and medical clinic. The vaginal secretion samples were collected between the months of October 2003 and August 2004, the Center for Health Manuel de Araújo Caldas, located in the neighborhood of Arthur Lundgren I in the City of Paulista, Pernambuco. We used 30 samples belonging to the genera Candida, Rhodotorula, Trichosporon and Kloeckera. All yeasts are deposited in the fungal collection - URM, Department of Mycology, Federal University of Pernambuco and were 
subjected to taxonomic confirmation according to the authors $(4,23,25)$ which are based on morphological and physiological evidence. The project was approved by the Ethics in Research of the Science Center Health, Federal University of Pernambuco, 304/2003-CEP/CCS Protocol.

\section{Sample Reactivation}

The stocked samples preserved in mineral oil were reactivated by growth in glycoside broth and then transferred to slants containing Sabouraud agar plus yeast extract $(\mathrm{SAB}+\mathrm{YE})$ (12).

For confirmation of the identification: Bovine bile water medium, $\mathrm{C}$ and $\mathrm{N}$ basic medium and sugar fermentation medium. For species confirmation, the classical methods of taxonomy of yeasts were utilized $(4,23,25)$.

\section{Procedures for assessing the antifungal activity of lectins}

Culture medium: The culture medium used for the procedure was RPMI 1640 (Sigma-Aldrich, USA) with Lglutamine and without sodium bicarbonate, buffered to $\mathrm{pH} 7.0$ with morfolinepropanesulfônico acid (MOPS) to $0165 \mathrm{M}$ (Sigma-Aldrich, USA). The medium was sterilized by membrane filtration with porosity of $0.22 \mu \mathrm{m}$ (Millipore).

Lectins: We used four lectins extracted from legumes, such as Dviol, DRL, ConBr and LSL, respectively extracted from Dioclea violacea, D. rostrata, Canavalia brasiliensis and Lonchocarpus sericeus. The first lectin was obtained from seeds of legumes from Rio Grande do Sul (Brazil) and the rest of the state of Ceará (Brazil). These lectins were purified (2, 8, $26,28)$ and kindly provided by the Laboratory of biologically active molecules from the Federal University of Ceará. After solubilization in sterile distilled water were prepared ten concentrations between 0.5 and $256 \mu \mathrm{g} / \mathrm{mL}$, followed by serial dilutions to achieve the final concentration 10 times higher than the concentration used in the procedure. Later, they were diluted (1:50) in RPMI 1640 to obtain the concentration of two times higher than necessary.

\section{Preparation of inoculum}

The inoculum were standardized according to the procedure adopted by the CLSI (15), where there was a peal of the microorganisms in tubes containing Sabouraud dextrose agar at room temperature $\left(\mathrm{RT}=28^{\circ} \mathrm{C} \pm 1^{\circ} \mathrm{C}\right)$. The inoculum was prepared by selecting five colonies with a diameter of about $1 \mathrm{~mm}$ to 24 hours of culture. The colonies were suspended in $5 \mathrm{ml}$ of sterile distilled water, where the resulting suspension was placed in a vortex shaker for 15 seconds and the cell density was adjusted in a spectrophotometer by adding sterile distilled water sufficient to obtain the equivalent transmittance of a standard solution of McFarland 0.5, at a wavelength of $530 \mathrm{~nm}$. This procedure provides a standard yeast suspension containing 1 × $10^{6}$ a $5 \times 10^{6}$ cells per $\mathrm{mL}$. The suspension of work is produced by making a 1:100 dilution followed by a 1:20 dilution of the standard suspension with RPMI 1640 liquid medium, resulting in a concentration of 5,0 x $10^{2}$ a $2,5 \times 10^{3}$ cells per $\mathrm{mL}^{2}$.

\section{Procedure for evaluation of antifungal activity}

The microtiter method in liquid medium was performed in accordance with the document M27-A2 (15) in sterile microtiter plates with lids (TPP, Switzerland) containing 96 wells with U-shaped (flat bottom) were placed $100 \mathrm{~mL}$ of lectins in rows 1 to 10 , with each concentration was placed in a row. In the wells of rows 11 and 12 were placed $100 \mu \mathrm{L}$ of RPMI 1640, which were the growth control and sterilization of the medium, respectively. These plates were stored at $-20^{\circ} \mathrm{C}$ until use.

In due course, was deposited in each well $100 \mu \mathrm{L}$ of standardized inoculum, as previously mentioned, and the microtiter plates were incubated at room temperature $(\mathrm{RT}=$ $28^{\circ} \mathrm{C} \pm 1^{\circ} \mathrm{C}$ ) for seven days for the interpretation of results.

\section{Data analysis}

Every experiment was performed in duplicate. The concentrations inhibitory and fungicidal (MIC and MFC) of 
each sample, geometric mean inhibitory concentrations and minimal fungicidal (GMMIC and GMMFC) determining the concentration able to inhibit $50 \%$ or $100 \%$ of samples $\left(\mathrm{MIC}_{50}\right.$ and $\mathrm{MIC}_{100}$, respectively).

Statistical analysis consisted of presentation of events in absolute numbers, percentages and averages, and used the Fisher exact test for the association of variables showing significance $(\mathrm{p}<0.05)$.

\section{Determination of minimum inhibitory concentration (MIC)} and minimal fungicidal concentration (MFC)

The determination of minimum inhibitory concentration of each sample was performed by visual observation of each well that showed a reduction of fungal growth and by reading the microtiter plates by the Microplate Manager program, model BenchMark Plus (Bio-Rad Laboratories Inc.) at 530nm. Taking into account the total growth $(100 \%)$ in the control well, the percentage reduction in growth was attributed to the remaining wells. In microdilution plates after incubation $\left(\mathrm{RT}=28^{\circ} \mathrm{C} \pm\right.$ $1{ }^{\circ} \mathrm{C}$ ), we observed the presence or absence of visible growth.

\section{RESULTS}

All yeast strains isolated from vaginal secretions were evaluated taxonomically, which were observed macroscopic and microscopic characteristics relevant to each species. The species of yeasts isolated from vaginal secretions tested in this study are shown in (Table 1).

Table 1. Yeast strains isolated from vaginal secretion from October 2003 to August 2004.

\begin{tabular}{|c|c|}
\hline Registration URM Culture Collection & Species \\
\hline 4987 & Candida albicans \\
\hline 4990 & C. albicans \\
\hline 4986 & C. albicans \\
\hline 4979 & C. azyma \\
\hline 4985 & C. geochares \\
\hline 4975 & C. guilliermondii \\
\hline 4976 & C. marítima \\
\hline 4983 & C. membranaefaciens \\
\hline 4982 & C. obtusa \\
\hline 4984 & C. parapsilosis \\
\hline 4970 & C. parapsilosis \\
\hline 4972 & C. robusta \\
\hline 4974 & C. sake \\
\hline 6088 & C. salmanticensis \\
\hline 4978 & C. shehatae \\
\hline 6084 & C. tropicalis \\
\hline 6090 & C. tropicalis \\
\hline 6089 & C. tropicalis \\
\hline 4989 & C. tropicalis \\
\hline 4981 & C. tsuchiyae \\
\hline 4980 & C.versatilis \\
\hline 5002 & Kloeckera apiculata \\
\hline 5092 & Rhodotorula glutinis \\
\hline 6085 & R. minuta \\
\hline 6086 & R. minuta \\
\hline 6087 & R. minuta \\
\hline 4971 & R. graminis \\
\hline 4988 & R. pallida \\
\hline 6083 & R. rubra \\
\hline 4973 & Trichosporon cutaneum \\
\hline
\end{tabular}


The DRL lectin showed antifungal activity in four isolates, with geometric mean concentrations of $128 \mu \mathrm{g} / \mathrm{mL}$ in C. guilliermondii (URM4975) and $4 \mu \mathrm{g} / \mathrm{mL}$ in C. shehatae (URM4978), 64 $\mu \mathrm{g} / \mathrm{mL}$ in C. membranaefaciens (URM4983) and $128 \mu \mathrm{g} / \mathrm{mL}$ in Kloeckera apiculata (URM5002).

$\mathrm{ConBr}$ showed antifungal activity in ten isolates, $C$. albicans (URM4987), C. guilliermondii (URM4975), C. membranaefaciens (URM4983), C. parapsilosis (URM4984), C. shehatae (URM4978), C. tropicalis (URM6084), C. tropicalis (URM6089), C. tropicalis (URM4989), K.apiculata (URM5002), T. cutaneum (URM4973) with geometric mean concentrations ranging from $2-256 \mu \mathrm{g} / \mathrm{mL}$. (Table 2 ).

Table 2. Determination of minimum inhibitory concentration of lectins and DRL ConBr in yeast strains isolated from vaginal secretions.

\begin{tabular}{|c|c|c|c|c|c|c|c|c|}
\hline Yeasts & *MICs & $\begin{array}{r}\mathrm{DR} \\
* \mathrm{MIC}_{30}\end{array}$ & ${ }^{\mathrm{L}} * \mathrm{MIC}_{100}$ & *GMMIC & *MICs & $\begin{array}{r}\mathrm{Cor} \\
* \mathrm{MIC}_{90}\end{array}$ & $\begin{array}{l}{ }^{\mathrm{nbr}} \\
\mathrm{MIC}_{100}\end{array}$ & *GMMIC \\
\hline species & $(\mu \mathrm{g} / \mathrm{mL})$ & $(\mu \mathrm{g} / \mathrm{mL})$ & $(\mu \mathrm{g} / \mathrm{mL})$ & $(\mu \mathrm{g} / \mathrm{mL})$ & $(\mu \mathrm{g} / \mathrm{mL})$ & $(\mu \mathrm{g} / \mathrm{mL})$ & $(\mu \mathrm{g} / \mathrm{mL})$ & $(\mu \mathrm{g} / \mathrm{mL})$ \\
\hline URM 4987 & $\mathrm{R}$ & $\mathrm{R}$ & $\mathrm{R}$ & $\mathrm{R}$ & 8 & 16 & ND & 11,3 \\
\hline URM 4990 & $\mathrm{R}$ & $\mathrm{R}$ & $\mathrm{R}$ & $\mathrm{R}$ & $\mathrm{R}$ & $\mathrm{R}$ & $\mathrm{R}$ & $\mathrm{R}$ \\
\hline URM 4986 & $\mathrm{R}$ & $\mathrm{R}$ & $\mathrm{R}$ & $\mathrm{R}$ & $\mathrm{R}$ & $\mathrm{R}$ & $\mathrm{R}$ & $\mathrm{R}$ \\
\hline URM 4979 & $\mathrm{R}$ & $\mathrm{R}$ & $\mathrm{R}$ & $\mathrm{R}$ & 8 & 8 & ND & 8 \\
\hline URM 4985 & $\mathrm{R}$ & $\mathrm{R}$ & $\mathrm{R}$ & $\mathrm{R}$ & $\mathrm{R}$ & R & $\mathrm{R}$ & $\mathrm{R}$ \\
\hline URM 4975 & 128 & 128 & ND & 128 & 8 & 16 & ND & 11,3 \\
\hline URM 4976 & $\mathrm{R}$ & $\mathrm{R}$ & $\mathrm{R}$ & $\mathrm{R}$ & $\mathrm{R}$ & $\mathrm{R}$ & $\mathrm{R}$ & $\mathrm{R}$ \\
\hline URM 4983 & 64 & 64 & ND & 64 & 2 & 8 & ND & 4 \\
\hline URM 4982 & $\mathrm{R}$ & $\mathrm{R}$ & $\mathrm{R}$ & $\mathrm{R}$ & 8 & 16 & ND & 11,3 \\
\hline URM 4984 & $\mathrm{R}$ & $\mathrm{R}$ & $\mathrm{R}$ & $\mathrm{R}$ & $\mathrm{R}$ & $\mathrm{R}$ & $\mathrm{R}$ & $\mathrm{R}$ \\
\hline URM 4970 & $\mathrm{R}$ & $\mathrm{R}$ & $\mathrm{R}$ & $\mathrm{R}$ & $\mathrm{R}$ & $\mathrm{R}$ & $\mathrm{R}$ & $\mathrm{R}$ \\
\hline URM 4972 & $\mathrm{R}$ & $\mathrm{R}$ & $\mathrm{R}$ & $\mathrm{R}$ & $\mathrm{R}$ & $\mathrm{R}$ & $\mathrm{R}$ & $\mathrm{R}$ \\
\hline URM 4974 & $\mathrm{R}$ & $\mathrm{R}$ & $\mathrm{R}$ & $\mathrm{R}$ & $\mathrm{R}$ & $\mathrm{R}$ & $\mathrm{R}$ & $\mathrm{R}$ \\
\hline URM 6088 & $\mathrm{R}$ & $\mathrm{R}$ & $\mathrm{R}$ & $\mathrm{R}$ & $\mathrm{R}$ & $\mathrm{R}$ & $\mathrm{R}$ & $\mathrm{R}$ \\
\hline URM 4978 & 4 & 4 & ND & 4 & 2 & 2 & ND & 2 \\
\hline URM 6084 & $\mathrm{R}$ & $\mathrm{R}$ & $\mathrm{R}$ & $\mathrm{R}$ & $\mathrm{R}$ & $\mathrm{R}$ & $\mathrm{R}$ & $\mathrm{R}$ \\
\hline URM 6090 & $\mathrm{R}$ & $\mathrm{R}$ & $\mathrm{R}$ & $\mathrm{R}$ & $\mathrm{R}$ & $\mathrm{R}$ & $\mathrm{R}$ & $\mathrm{R}$ \\
\hline URM 6089 & $\mathrm{R}$ & $\mathrm{R}$ & $\mathrm{R}$ & $\mathrm{R}$ & $\mathrm{R}$ & $\mathrm{R}$ & $\mathrm{R}$ & $\mathrm{R}$ \\
\hline URM 4989 & $\mathrm{R}$ & $\mathrm{R}$ & $\mathrm{R}$ & $\mathrm{R}$ & 8 & 16 & ND & 11,3 \\
\hline URM 4981 & $\mathrm{R}$ & $\mathrm{R}$ & $\mathrm{R}$ & $\mathrm{R}$ & $\mathrm{R}$ & $\mathrm{R}$ & $\mathrm{R}$ & $\mathrm{R}$ \\
\hline URM 4980 & $\mathrm{R}$ & $\mathrm{R}$ & $\mathrm{R}$ & $\mathrm{R}$ & $\mathrm{R}$ & $\mathrm{R}$ & $\mathrm{R}$ & $\mathrm{R}$ \\
\hline URM 5002 & 64 & 256 & ND & 128 & 256 & 256 & ND & 256 \\
\hline URM 5092 & $\mathrm{R}$ & $\mathrm{R}$ & $\mathrm{R}$ & $\mathrm{R}$ & $\mathrm{R}$ & $\mathrm{R}$ & $\mathrm{R}$ & $\mathrm{R}$ \\
\hline URM 6085 & $\mathrm{R}$ & $\mathrm{R}$ & $\mathrm{R}$ & $\mathrm{R}$ & $\mathrm{R}$ & $\mathrm{R}$ & $\mathrm{R}$ & $\mathrm{R}$ \\
\hline URM 6086 & $\mathrm{R}$ & $\mathrm{R}$ & $\mathrm{R}$ & $\mathrm{R}$ & $\mathrm{R}$ & $\mathrm{R}$ & $\mathrm{R}$ & $\mathrm{R}$ \\
\hline URM 6087 & $\mathrm{R}$ & $\mathrm{R}$ & $\mathrm{R}$ & $\mathrm{R}$ & $\mathrm{R}$ & $\mathrm{R}$ & $\mathrm{R}$ & $\mathrm{R}$ \\
\hline URM 4971 & $\mathrm{R}$ & $\mathrm{R}$ & $\mathrm{R}$ & $\mathrm{R}$ & $\mathrm{R}$ & $\mathrm{R}$ & $\mathrm{R}$ & $\mathrm{R}$ \\
\hline URM 4988 & $\mathrm{R}$ & $\mathrm{R}$ & $\mathrm{R}$ & $\mathrm{R}$ & $\mathrm{R}$ & $\mathrm{R}$ & $\mathrm{R}$ & $\mathrm{R}$ \\
\hline URM 6083 & $\mathrm{R}$ & $\mathrm{R}$ & $\mathrm{R}$ & $\mathrm{R}$ & $\mathrm{R}$ & $\mathrm{R}$ & $\mathrm{R}$ & $\mathrm{R}$ \\
\hline URM 4973 & $\mathrm{R}$ & $\mathrm{R}$ & $\mathrm{R}$ & $\mathrm{R}$ & 2 & 8 & ND & 4 \\
\hline ATCC 22019 & $\mathrm{R}$ & $\mathrm{R}$ & $\mathrm{R}$ & $\mathrm{R}$ & $\mathrm{R}$ & $\mathrm{R}$ & $\mathrm{R}$ & $\mathrm{R}$ \\
\hline ATCC 6258 & $\mathrm{R}$ & $\mathrm{R}$ & $\mathrm{R}$ & $\mathrm{R}$ & $\mathrm{R}$ & $\mathrm{R}$ & $\mathrm{R}$ & $\mathrm{R}$ \\
\hline
\end{tabular}

* Average results

MIC: minimum inhibitory concentrations

$\mathrm{MIC}_{50}$ and $\mathrm{MIC}_{100}$ : minimum concentration able to inhibit $50 \%$ and $100 \%$ of samples.

GMMIC: geometric mean minimum inhibitory concentration.

ND: not determined

$\mathrm{R}$ : resistance 
LSL showed no antifungal activity in any of the isolates, parapsilosis (URM4984), C. shehatae (URM4978), C. while DvioL showed antifungal activity in thirteen of the tropicalis (URM6084), C. tropicalis (URM6090), C. tropicalis strains tested, C. albicans (URM4987), C.albicans (URM6089), $\quad$ C. $\quad$ tropicalis (URM4989), K.apiculata (URM4986), C. guilliermondii (URM4975), C. (URM5002), R. glutinis (URM5092), with geometric mean membranaefaciens (URM4983), C. obtusa (URM4982), C. concentrations ranging from 8-256 $\mu \mathrm{g} / \mathrm{mL}$ (Table 3).

Table 3. Determination of minimum inhibitory concentration of lectins and LSL DvioL for yeast strains isolated from vaginal secretions.

\begin{tabular}{|c|c|c|c|c|c|c|c|c|}
\hline \multirow{3}{*}{$\begin{array}{l}\text { Yeasts } \\
\text { species }\end{array}$} & \multicolumn{4}{|c|}{ LSL } & \multicolumn{4}{|c|}{ DvioL } \\
\hline & *MICs & $* \mathrm{MIC}_{90}$ & $* \mathrm{MIC}_{100}$ & *GMMIC & *MICs & $* \mathrm{MIC}_{90}$ & $* \mathrm{MIC}_{100}$ & *GMMIC \\
\hline & $(\mu \mathrm{g} / \mathrm{mL})$ & $(\mu \mathrm{g} / \mathrm{mL})$ & $(\mu \mathrm{g} / \mathrm{mL})$ & $(\mu \mathrm{g} / \mathrm{mL})$ & $(\mu \mathrm{g} / \mathrm{mL})$ & $(\mu \mathrm{g} / \mathrm{mL})$ & $(\mu \mathrm{g} / \mathrm{mL})$ & $(\mu \mathrm{g} / \mathrm{mL})$ \\
\hline URM 4987 & $\mathrm{R}$ & $\mathrm{R}$ & $\mathrm{R}$ & $\mathrm{R}$ & 16 & 16 & ND & 16 \\
\hline URM 4990 & $\mathrm{R}$ & $\mathrm{R}$ & $\mathrm{R}$ & $\mathrm{R}$ & $\mathrm{R}$ & $\mathrm{R}$ & $\mathrm{R}$ & $\mathrm{R}$ \\
\hline URM 4986 & $\mathrm{R}$ & $\mathrm{R}$ & $\mathrm{R}$ & $\mathrm{R}$ & 32 & 32 & ND & 32 \\
\hline URM 4979 & $\mathrm{R}$ & $\mathrm{R}$ & $\mathrm{R}$ & $\mathrm{R}$ & 32 & 32 & ND & 32 \\
\hline URM 4985 & $\mathrm{R}$ & $\mathrm{R}$ & $\mathrm{R}$ & $\mathrm{R}$ & $\mathrm{R}$ & $\mathrm{R}$ & $\mathrm{R}$ & $\mathrm{R}$ \\
\hline URM 4975 & $\mathrm{R}$ & $\mathrm{R}$ & $\mathrm{R}$ & $\mathrm{R}$ & 32 & 32 & ND & 32 \\
\hline URM 4976 & $\mathrm{R}$ & $\mathrm{R}$ & $\mathrm{R}$ & $\mathrm{R}$ & 32 & 32 & ND & 32 \\
\hline URM 4983 & $\mathrm{R}$ & $\mathrm{R}$ & $\mathrm{R}$ & $\mathrm{R}$ & 128 & 128 & ND & 128 \\
\hline URM 4982 & $\mathrm{R}$ & $\mathrm{R}$ & $\mathrm{R}$ & $\mathrm{R}$ & 32 & 32 & ND & 32 \\
\hline URM 4984 & $\mathrm{R}$ & $\mathrm{R}$ & $\mathrm{R}$ & $\mathrm{R}$ & $\mathrm{R}$ & $\mathrm{R}$ & $\mathrm{R}$ & $\mathrm{R}$ \\
\hline URM 4970 & $\mathrm{R}$ & $\mathrm{R}$ & $\mathrm{R}$ & $\mathrm{R}$ & $\mathrm{R}$ & $\mathrm{R}$ & $\mathrm{R}$ & $\mathrm{R}$ \\
\hline URM 4972 & $\mathrm{R}$ & $\mathrm{R}$ & $\mathrm{R}$ & $\mathrm{R}$ & 32 & 64 & ND & 45,2 \\
\hline URM 4974 & $\mathrm{R}$ & $\mathrm{R}$ & $\mathrm{R}$ & $\mathrm{R}$ & $\mathrm{R}$ & $\mathrm{R}$ & $\mathrm{R}$ & $\mathrm{R}$ \\
\hline URM 6088 & $\mathrm{R}$ & $\mathrm{R}$ & $\mathrm{R}$ & $\mathrm{R}$ & $\mathrm{R}$ & $\mathrm{R}$ & $\mathrm{R}$ & $\mathrm{R}$ \\
\hline URM 4978 & $\mathrm{R}$ & $\mathrm{R}$ & $\mathrm{R}$ & $\mathrm{R}$ & 8 & 8 & ND & 8 \\
\hline URM 6084 & $\mathrm{R}$ & $\mathrm{R}$ & $\mathrm{R}$ & $\mathrm{R}$ & $\mathrm{R}$ & $\mathrm{R}$ & $\mathrm{R}$ & $\mathrm{R}$ \\
\hline URM 6090 & $\mathrm{R}$ & $\mathrm{R}$ & $\mathrm{R}$ & $\mathrm{R}$ & 32 & 32 & ND & 32 \\
\hline URM 6089 & $\mathrm{R}$ & $\mathrm{R}$ & $\mathrm{R}$ & $\mathrm{R}$ & $\mathrm{R}$ & $\mathrm{R}$ & $\mathrm{R}$ & $\mathrm{R}$ \\
\hline URM 4989 & $\mathrm{R}$ & $\mathrm{R}$ & $\mathrm{R}$ & $\mathrm{R}$ & 8 & 8 & ND & 8 \\
\hline URM 4981 & $\mathrm{R}$ & $\mathrm{R}$ & $\mathrm{R}$ & $\mathrm{R}$ & $\mathrm{R}$ & $\mathrm{R}$ & $\mathrm{R}$ & $\mathrm{R}$ \\
\hline URM 4980 & $\mathrm{R}$ & $\mathrm{R}$ & $\mathrm{R}$ & $\mathrm{R}$ & $\mathrm{R}$ & $\mathrm{R}$ & $\mathrm{R}$ & $\mathrm{R}$ \\
\hline URM 5002 & $\mathrm{R}$ & $\mathrm{R}$ & $\mathrm{R}$ & $\mathrm{R}$ & 16 & 256 & ND & 64 \\
\hline URM 5092 & $\mathrm{R}$ & $\mathrm{R}$ & $\mathrm{R}$ & $\mathrm{R}$ & 256 & 256 & ND & 256 \\
\hline URM 6085 & $\mathrm{R}$ & $\mathrm{R}$ & $\mathrm{R}$ & $\mathrm{R}$ & $\mathrm{R}$ & $\mathrm{R}$ & $\mathrm{R}$ & $\mathrm{R}$ \\
\hline URM 6086 & $\mathrm{R}$ & $\mathrm{R}$ & $\mathrm{R}$ & $\mathrm{R}$ & $\mathrm{R}$ & $\mathrm{R}$ & $\mathrm{R}$ & $\mathrm{R}$ \\
\hline URM 6087 & $\mathrm{R}$ & $\mathrm{R}$ & $\mathrm{R}$ & $\mathrm{R}$ & $\mathrm{R}$ & $\mathrm{R}$ & $\mathrm{R}$ & $\mathrm{R}$ \\
\hline URM 4971 & $\mathrm{R}$ & $\mathrm{R}$ & $\mathrm{R}$ & $\mathrm{R}$ & $\mathrm{R}$ & $\mathrm{R}$ & $\mathrm{R}$ & $\mathrm{R}$ \\
\hline URM 4988 & $\mathrm{R}$ & $\mathrm{R}$ & $\mathrm{R}$ & $\mathrm{R}$ & $\mathrm{R}$ & $\mathrm{R}$ & $\mathrm{R}$ & $\mathrm{R}$ \\
\hline URM 6083 & $\mathrm{R}$ & $\mathrm{R}$ & $\mathrm{R}$ & $\mathrm{R}$ & $\mathrm{R}$ & $\mathrm{R}$ & $\mathrm{R}$ & $\mathrm{R}$ \\
\hline URM 4973 & $\mathrm{R}$ & $\mathrm{R}$ & $\mathrm{R}$ & $\mathrm{R}$ & $\mathrm{R}$ & $\mathrm{R}$ & $\mathrm{R}$ & $\mathrm{R}$ \\
\hline ATCC 22019 & $\mathrm{R}$ & $\mathrm{R}$ & $\mathrm{R}$ & $\mathrm{R}$ & $\mathrm{R}$ & $\mathrm{R}$ & $\mathrm{R}$ & $\mathrm{R}$ \\
\hline ATCC 6258 & $\mathrm{R}$ & $\mathrm{R}$ & $\mathrm{R}$ & $\mathrm{R}$ & $\mathrm{R}$ & $\mathrm{R}$ & $\mathrm{R}$ & $\mathrm{R}$ \\
\hline
\end{tabular}

* Average results

MIC: minimum inhibitory concentrations

$\mathrm{MIC}_{50}$ and $\mathrm{MIC}_{100}$ : minimum concentration able to inhibit $50 \%$ and $100 \%$ of samples.

GMMIC: geometric mean minimum inhibitory concentration.

ND: not determined

$\mathrm{R}$ : resistance 
Four of the isolates, C. guilliermondii (URM4975), $C$. shehatae (URM4978), C. membranaefaciens (URM4983) and $K$. apiculata (URM5002), showed sensitivity to the three lectins with antifungal activity, DRL, and ConBr DvioL.

In addition to the strains isolated from vaginal discharge, were included two control organisms, $C$. parapsilosis (ATCC22019) and C. krusei (ATCC6258), both were resistant to concentrations of lectins tested. According to the p-values of Fisher's exact test $(\mathrm{p}<0.05)$, with no differences between species in relation to sensitivity to the lectins tested, except $\mathrm{ConBr}$, where the resistance was observed only in samples of Candida and Rhodotourula.

\section{DISCUSSION}

There are reports of other lectins that can bind to glucose, mannose and $\mathrm{N}$-acetylglucosamine with antifungal activity. Among these, the lectin TEL has promoted 57\% inhibition of growth of Sacchromyces cerevisiae, Fusarium moniliforme and Colletotrichum lindemuthianum in the concentration of $280 \mu \mathrm{g} / \mathrm{mL}(18)$ and lectin AML (glucose/mannose) that caused $41 \%$ inhibition of growth of $F$. solani, $F$. oxysporum and Colletotrichum musae in the concentration of $100 \mu \mathrm{g} / \mathrm{mL}$ (16). Trindade et al. (35) found the antifungal activity of lectins "jackin"and "frutackin" (N-acetylglucosamine) to the $2.25 \mathrm{mg} / \mathrm{mL}$ S. cerevisiae and Fusarium moniliforme.

The antifungal activity of lectins has been detected in concentrations ranging from the $100 \mu \mathrm{g} / \mathrm{mL} 10.58 \mathrm{mg} / \mathrm{mL}$ for different species of fungi. There are reports on antifungal activity of lectins against yeasts as Sacchromyces cerevisiae $(17,35,36)$.

Lectins from legumes without antifungal activity and binding specificity to glucose and mannose have also been reported by other authors, such as the lectin pea Pisum sativum var. macrocarpon (42), Chinese chestnut Castanea mollisima (30) and bean Canavalia gladiata (37).

Inhibition of fungal growth by the action of lectins, appears to be due to inhibition of spore germination as well as the growth of the mycelium (21). The exact mechanism of action has not yet been elucidated, but there seems to be alteration in the fungal cell wall due to changes in the synthesis of chitin, a deficiency in cell wall deposition. Lectins that bind to chitin showed significant antifungal effect, however, the presence or absence of this change is dependent on the combination of the fungus with the lectin $(21,33)$.

The antifungal activity of lectins may vary depending on the species examined. Studies have not found the antifungal activity AMML lectin with binding affinity for galactose and its derivatives in relation to Rhizoctonia solani and Mycospharella arachidicola in concentration up $200 \mu \mathrm{g} / \mathrm{mL}$ (40). Did not observe this activity to SCL lectin with binding affinity for $\mathrm{N}$-acetylgalactosamine, for $S$. cerevisiae, $C$. albicans, Penicillium diditatum until the concentration of $1 \mathrm{mg} / \mathrm{ml}$. However, these authors found the antifungal activity of those lectins for other species of fungi (13).

Lectins DRL ConBr and DvioL have antifungal activity, against yeasts isolated from vaginal secretion, thus forming a promising field for development of new therapeutic strategies for vaginal yeast infections and the consequent promotion of women's health.

\section{ACKNOWLEDGEMENTS}

The authors acknowledge CNPq, UFPE and Laboratory of Biologically Active Molecular, Universidade Federal do Ceará and the teacher Lusinete Aciole de Queiroz (in memoriam).

\section{REFERENCES}

1. Alencar, N.M.; Cavalcante, C.F.; Vasconcelos, M.P.; Leite, K.B.; Aragão, K.S.; Assreuy, A.M.; Nogueira, N.A.; Cavada, B.S.; Vale, M.R. (2005). Anti-inflammatory and antimicrobial effect of lectin from Lonchocarpus sericeus seeds in an experimental rat model of infectious peritonitis. J. Pharm. Pharmacol. (57), 919-922.

2. Alencar, N.M.; Teixeira, E.H.; Assreuy, A.M.S.; Cavada, B.S.; Flores, C,A; Ribeiro, R.A. (1999). Leguminous lectins as tools for studying the role of sugar residues in leukocyte recruitment. Mediators. Inflamm. (8), 107-13. 
3. Barbosa, T.; Arruda, S.; Cavada, B.; Grangeiro, T. B.; Freitas, L. A. R.; Barral-Netto, M. (2001). In vivo lymphocyte activation and apoptosis by lectins of Diocleinae subtribe. Mem. Inst. Oswaldo Cruz. (96), 673-678.

4. Barnett J.A.; Payne R.W.; Yarrow D. (2000). Yeasts: Characteristics and identification. 3nd Edition. Cambridge University Press, Cambridge, UK.

5. Barral-Netto, M.; Santos, S.B.; Moreira, R.A.; Oliveira, J.T.A.; Barral, A.; Moreira, L.I.M.; Santos, C.F.; Cavada, B.S. (1992). Human lymphocyte stimulation by lectins from Brazilian leguminous seeds. Immunol. Invest. (21), 297-303.

6. Barral-Netto, M.; Von Sohsten, R. L.; Teixeira, M.; Santos, W. L.; Pompeu, M. L.; Moreira, R. A.; Oliveira, J. T.; Cavada, B. S.; Falcoff, E.; Barral, A. (1996). In vivo protective effect of the lectin from Canavalia brasiliensis on Balb/ mice infected by Leishmania amazonensis. Acta Tropica. (60), 237-250.

7. Brockaert, W.F.; Van Parijs, J.; Leyns, F.; Joos, H.; Peumans, W.J. (1989). A chitin-binding lectin from stinging nettle rhizomes with antifungal properties. Science. (245), 1100-1103.

8. Cavada, B.S.; Grangeiro, T.B.; Ramos, M.V.; Cordeiro, E.F.; Oliveira, J.T.A.; Moreira, R.A. (1996). Isolation and partial characterization of a lectin from Dioclea rostrata Benth seeds. R. Bras. Fisio. Veg. (8), 31-36.

9. Cavada, B.S.; Madeira, S.V.F.; Calvete, J.J.; Souza, L.A.; Bomfim, L.R.; Dantas, A.R.; Lopes, M.C.; Grangeiro, T.B.; Freitas, B.T.; Pinto, V.P.; Leite, K.B.; Ramos, M.V. (2000). Purification, chemical, and immunochemical properties of a new lectin from Mimosoideae (Parkia discolor). Prep. Biochem. Biotechnol. (30), 271-280.

10. Cavada, B. S.; Moreira, R. A.; Oliveira, J. T. A.; Grangeiro, T. B. (1993). Primary structures and functions of plant lectins. R. Bras. Fisio. Veg. (5), 193-201.

11. Cavada, B.S.; Santos, C.F.; Grangeiro, T.B.; Nunes, E.P.; Sales, P.V.P.; Ramos, R.L.; Sousa, F.A.M.; Crisostomo, C.V.; Calvete, J.J. (1998). Purification and characterization of a lectin from seeds of Vatairea macrocarpa duke. Phytochem. (49), 675-680.

12. Chaves, G.M; Cavalcanti, M.A.Q; Porto, A.L.F. Pathogenicity characteristics of stocked and fresh yeasts strains. Braz. J. Microbiol. 2003, vol.34, n.3, pp. 197-202.

13. Chumkhunthod, P.; Rodtong, S.; Lambert, S.J.; Fordham-Skelton, A.P.; Rizallah, P.J.; Wilkinson, M.C.; Reynolds, C.D. (2006). Purification and characterization of an N-acetyl-D-galactosamine-specific lectin from the edible mushroom Schizophyllum commune. Biochimica et Biophysica Acta (General Subjects). 1760 (3), 326-332.

14. Ciopraga, J.; Gozia, O.; Tudor, R.; Brezuica, L.; Doyle, R.J. (1999). Fusarium sp. growth inhibition by wheat germ agglutinin. Biochem. Biophysi. Acta. (1428), 424-432.

15. Clinical and Laboratory Standards Institute (CLSI). (2002). Método de referência para testes de diluição em caldo para determinação da sensibilidade de leveduras à terapia antifúngica. Norma aprovada, M27-
A, 2nd. Edition, 22(5).

16. Damico, D.C.S.; Freire, M.G.M.; Gomes, V.M.; Toyama, M.H.; Marangoni, S.; Novello, J.C.; Macedo, M.L.R. (2003). Isolation and characterization of a lectin from Annona muricata seeds. J. Protein. Chem. (22), 655-661.

17. Freire, M.G.M.; Gomes, V.M.; Corsini, R.E.; Machado, O.L.T.; De Simone, S.G.; Novello, J.C.; Maragoni, S.; Macedo, M.L.R. (2002). Isolation and partial characterization of a novel lectin from Talisia esculenta seeds that interferes with fungal growth. Plant Physiology and Biochemistry.40(1), 61-68.

18. Freire, M.G.M.; Gomes V.M.; Corsini, R.E.; Machado, O.L.T.; De Simone, S.G.; Novello, J.C.; Marangoni, S.; Macedo, M.L.R. (2002). Isolation and partial characterization of a novel lectin from Talisia esculenta seeds that interferes with fungal growth. Plant. Physiol. Biochem. (40), 61-68.

19. Gomes, J.C.; Cavada, B.S.; Moreira, R.A.; Oliveira, J.T.A. (1994). Histamine release induced by glucose (mannose)-specific lectins isolated from Brazilian plants. Comparison with concanavalin A. Agents Actions (41), 132-135.

20. Gozia, O.; Ciopraga, J.; Bentia, T.; Lungu, M.; Zamfirescu, I.; Tudor, R.; Roseanu, A.; Nitu, F. (1993). Antifungal properties of lectin and new chitinases from potato tubers. C. R. Acad. Sci. III. (316), 788-92.

21. Griffin, D.H. (1993). Fungal Physiology. 2.ed. Wiley-Liss: New York, 458.

22. Hernández, E.S.; Santiago, A.P.; Campos, E.P.; Alva, F.C. (2003). Efecto de la concanavalina A en el cultivo del fitopatógeno Ustilago maydis. Interciencia (28), 276-280.

23. Kreger-Van Rij., N.J.W.(1984). The yeast: a taxonomic study. Elsevier Sci. Publication, Amsterdan.

24. Lis, H.; Sharon, N. (2003). Lectins: carbohydrate-specific proteins that mediate cellular recognition. Chem. Rev. (98), 637-674.

25. Lodder, J. (1970). The Yeast: a taxonomic study. Oxford: North Holland Publishing Company, 1385.

26. Moreira, R. A.; Cavada, B. S. (1984). Lectin from Canavalia brasiliensis (MART). Isolation, characterization and behavior during germination, Biol. Plant. (Prague). (26), 113-120.

27. Moreira, R.A.; Silva, L.M.A.; Horta, A.C.G.; Oliveira, J.T.A.; Cavada, B.S. (1993). Lectin from Canavalia brasiliensis Mart. Behavior during maturation and detection of a lectin precursor. R. Bras. Fisio. Veg. (5), 133-138.

28. Moreira, R.A.; Cordeiro, E.F.; Ramos, M.V.; Grangeiro, T.B.; Martins, J.L.; Oliveira, J.T.A.; Cavada, B.S. (1996). Isolation and partial characterization of a lectin from seeds of Dioclea violacea. R. Bras. Fisio. Veg. (8), 23-29.

29. Ngai, P.H.K.; Ng, T.B. (2004). A mushroom (Ganoderma capense) lectin with spectacular thermostability, potent mitogenic activity on 
splenocytes, and antiproliferative activity toward tumor cells. Biochem. Biophys. Res. Commun. (314), 988-993.

30. Ng, T.B.; Yu, Y.L.; Chu, K.T. (2002). Isolation of a novel legumin-like lectin with potent hemagglutinating activity from seeds of the Chinese chestnut Castanea mollisima. Comp Biochem Physiol. C. Toxicol. Pharmacol. (133), 453-460.

31. Napimoga, M.H.; Cavada, B.S.; Alencar, N.M.N.; Mota, M.L.; Bittencourt, F.S.; Alves-Filho, J.C.; Grespan, R.; Gonçalves, R.B.; Clemente-Napimoga, J.T.; Freitas, A.; Parada, C.A.; Ferreira, S.H.; Cunha, F.Q. (2007). Lonchocarpus sericeus lectin decreases leukocyte migration and mechanical hypernociception by inhibiting cytokine and chemokines production. Int. Immunopharmacol. (7), 824-835.

32. Pérez-Santiago, A.; Saavedra, E.; Pérez Camposa, E.; Córdoba, F. (2000). Effect of plant lectins on Ustilago maydis "in vitro". Cell. Mol. Life Sci. (57), 1986-1989.

33. Peumans, W.J.; Van Damme, E.J.M. (1995). Lectins as plant defense proteins. Plant Physiology.109(2),347-352.

34. Rodriguez, D.; Cavada, B.S.; Oliveira, J.T.A.; Moreira, R.A.; Russo, M. (1992). Differences in macrophage stimulation and leukocyte accumulation in response to intraperitoneal administration of glucose/mannose-binding lectins. Braz. J. Med. Biol. Res. (25), 823-826.

35. Trindade, M.B.; Lopes, J.L.S.; Soares-Costa, A.; Monteiro-Moreira, A.C.; Moreira, R.A.; Oliva, M.L.V.; Beltramini, L.M. (2006). Structural characterization of novel chitin-binding lectins from the genus
Artocarpus and their antifungal activity. Biochimica et Biophysica Acta (Proteins \& Proteomics).1764(1),146-152.

36. Viard, I. B.; Al-Mahmood, S.; Streiblova, E.; Bonaly, R. (1993). Alternate interactions of the o-galactose-specific yeast lectin $\mathrm{Kb}-\mathrm{CWL} \mathrm{I}$ with sensitive yeast strains. FEMS Microbiology Letters. 107(1),17-24.

37. Wong, J.H.;Wong, C.C.T.; Ng, T.B. (2006). Purification and characterization of a galactose-specific lectin with mitogenic activity from pinto beans. Biochem. Biophysi. Acta. (1760), 808-813.

38. Wong, J.H.; Ng, T.B. (2003). Purification of a trypsin-stable lectin with antiproliferative and HIV-1 reverse transcriptase inhibitory activity. Biochem. Biophys. Res. Commun. (301), 545-550.

39. Wong, J.H.; $\mathrm{Ng}$, T.B. (2005). Isolation and characterization of a glucose/mannose/rhamnos especific lectin from the knife bean Canavalia gladiata. Arch. Biochem. Biophys. (439), 91-98.

40. Yan, Q.; Jiang, Z.; Yang, S.; Deng, W.; Han, L. (2005). A novel homodimeric lectin from Astragalus mongholicus with antifungal activity. Archives of Biochemistry and Biophysics, 442 (1), 72-81.

41. Ye, X.Y.; Ng, T.B.; Tsang, P.W.K.; Wang, J. (2001). Isolation of a homodimeric lectin with antifungal and antiviral activities from red kidney bean (Phaseolus vulgaris). J. Protein. Chem. (20), 367-375.

42. Ye, X.; Ng, T.B. (2001). Isolation of lectin and albumin from Pisum sativum var. macrocarpon ser. cv. sugar snap. Int. J. Biochem. Cell. Biol. (33), 95-102. 